\title{
Are Male Employees Promoted More Often Than Females Who Are Just As Qualified?
}

Charmaine C. Walters Balfour, Nova Southeastern University, USA Bahaudin G. Mujtaba, Nova Southeastern University, USA

\begin{abstract}
The purpose of this research is to determine if males are promoted faster than females who are equally qualified. Statistics based on empirical studies have shown that from the number of students who have pursued degrees from the undergraduate level to the master's level, females outnumber males by far. One can therefore only conclude (all things being equal) that academically there are more qualified females than males in the workplace. However when you look on companies' corporate websites, there are more males than females in top management positions. Data were collected from a sample of 130 professionals who varied by gender, age, education, work experience and minority or majority status. The results of this study demonstrate that gender discrimination is not a perceptual barrier in promotional opportunities. Implications for manager and employees are discussed.
\end{abstract}

Keywords: gender, promotion, discrimination, age, work experience, education, and corporate workplace.

\section{INTRODUCTION TO WOMEN IN THE WORKPLACE}



raditionally, it was universally agreed that the woman's duty was to stay at home, and take care of the household, cooking and cleaning. After the men went to war during World War II, women were forced to assume the men's roles. When the men returned from war, women still remained a part of the workforce although treated inferiorly to men. In recent years women have made considerable progress procuring professional, supervisory, and middle-level management positions in organizations, largely due to government legislation (Aldefer, Tucker, Morgan and Drasgow, 1983; Bell, 1990; Pettigrew and Martin, 1987). Women do not seemingly have a problem being recruited, but when it reaches the advancement stage then there comes the challenge (Landau, 1995). However, facts in 2009 show that only about $13 \%$ of top executives are now females and this is only a one percent increase from 2007 data. Gender issues are now and probably will remain for the foreseeable future highly significant aspects of both the theory and practice of administration. The presence of a glass ceiling is a prominent issue in American organizational culture (Bullard and Wright, 1993). Today the source of the barriers to equal employment opportunities is a subtle and indirect form of discrimination that might not even be recognized by its perpetrators (Pettigrew and Martin, 1987). The paper seeks to determine how real gender discrimination perceptions are, the possible causes of such perceptions, and actions that can be taken to avoid such forms of discriminatory practices in the workplace. The main research question for this quantitative study is to determine if men are promoted at a faster rate than women who are equally qualified.

\section{EQUALITY VERSUS INEQUALITY}

Female employees still feel threatened by the possibility of being denied a promotion because of their gender. It is generally believed that promotion and career development opportunities for females in the American workplace, although better than they once were several decades ago, are still not on par with men, as gender stereotypes and discriminatory practices still exist in many workplaces. As such, it is a moral imperative for managers and employers to take assertive actions to create a company culture which makes it clear that any form of illegal discrimination will not be tolerated in any way, shape or form. A study was done by Carole Adair (1994), at the Colorado State University, to determine what conditions are required for women to attain top executive positions. An ethnographic study was conducted at a hospital. An in-depth data gathering technique using 
observation, interviews and documentation was used to investigate factors such as education/skills, influences, support, barriers and corporate culture. Adair findings revealed that education, mentorship, opportunity, attitude and having a career plan were some of the factors that contribute to women attaining top positions.

Prior research has shown that employees learn by coping with new experiences. However, gender differences in job moves described in 952 Wall Street Journal announcements of senior management appointments found that women's new positions were more similar to their previous positions than was true for their male counterparts. Women were less likely than men to be promoted to the management level or move to new organizations, and a greater proportion of women than men were appointed to line positions with prior female incumbents. Among managers in staff positions, women were less likely than were men to move to line positions or different organizational functions. Taken together, these findings raise questions about whether women's job moves offered career benefits that were comparable to those received by men (Lyness \& Schrader, 2006).

\section{PERCEPTION OR REALITY}

Are males in fact being given promotional preferences over females or is it just a perception due partly to the higher ratio of women within most organizations? Sharon Foley (1998) from the University of Connecticut conducted a research on the effects of the actual and perceived glass ceiling on perceptions of promotion fairness. The results of structural equation modeling revealed that the lower the percentage of women and minority partners in one's firm, the higher the perceived glass ceiling In addition, the higher the perceived glass ceiling, the lower one's advancement expectations, organizational commitment, job satisfaction, and the higher one's intention to leave the firm. Finally, fairness perceptions were positively related to advancement aspirations and expectations, organizational commitment, and job satisfaction, and negatively related to intentions to leave the firm (Foley, 1998).

A study done by Lyness and Thompson (2000) compares the careers of matched samples of 69 female executives and 69 male executives by examining perceived barriers and facilitators of advancement, self-reported developmental experiences, and career histories. Consistent with tokenism theory, women reported greater barriers, such as lack of culture fit and being excluded from informal networks, and greater importance of having a good track record and developing relationships to facilitate advancement than did men. Career success, measured by organizational level and compensation, was positively related to breadth of experience and developmental assignments for both genders, but successful women were less likely than successful men to report that mentoring facilitated their advancement. Developmental experiences and career histories were similar for female and male executives, but men had more overseas assignments and women had more assignments with non-authority relationships (Lyness \& Thompsom, 2000).

Perhaps culture makes a difference in the promotion of male and female candidates in the workplace. Hofstede (1980) said that culture is "the collective programming of the mind" and defined four cultural dimensions that described fundamental similarities and differences in human behavior, attitudes and decision-making. These are masculinity/femininity, power distance, individualism/collectivism and uncertainty avoidance. Regardless of cultural dimensions, the U.S. is not the only country which seems to have challenges related to the promotion of women in higher positions. Countries such as Greece, United Kingdom, Australia, and many others seem to have similar concerns in the workplace.

Women are vastly underrepresented in corporate Greece. One widely accepted explanation for this situation is the negative stereotypes about women as managers (Mihail, 2006). In the study conducted by Mihail, it was found that business students' attitudes toward women in management are primarily shaped by their own gender. This study, employing the Women as Managers Scale, found that male business students hold relatively negative stereotypic attitudes compared to their female counterparts. In addition, it was found that gender was by far the most influential factor in accounting for the difference in attitudes (Mihail, 2006).

Other studies have shown that some $89.5 \%$ of FTSE 100 company directors in the United Kingdom are men. A greater number of women are securing roles as independent directors. They comprise $6.8 \%$ of non-executive directors of the biggest companies, up from $3.1 \%$ a decade ago (Parkinson, 2006). Research by the corporate 
governance specialist Manifest found the rate of female appointments to top positions had slowed markedly and the trend towards smaller boards presented even fewer opportunities.

A research was done by Winchester et al. (2006) to determine if under-representation of women in Australian universities reflects barriers in the academic promotion process. Implicitly, most interviewees accepted the premise that women experienced barriers in the promotion process, including reticence in applying and stereotypically gendered notions of merit. However, the analysis of promotions data showed a more encouraging picture. Application rates and success rates for women are similar to men's and, at professorial level, slightly higher. Nonetheless women remain under-represented at senior levels, comprising only $16 \%$ of the professoriate (Winchester, Lorenzo, Browning \& Chesterman, 2006).

\section{GENDER AND PAY DISCRIMINATION IN RETAIL}

While perceptions regarding discrimination can vary from person to person and from workplace to workplace, facts about discrimination tends to remain consistent in the corporate environment. Unfortunately, the corporate world has seen many cases where managers have overtly (intentionally) and covertly (secretly behind the scenes) been discriminating against individuals because of their age, culture, gender, race, religion, sexual orientation, body size, disability, etc. (Mujtaba, 2007). For example, within the last few decades, Home Depot paid $\$ 104$ million to settle a gender lawsuit; Coca Cola had to pay \$192.5 million for racial discrimination; Publix Super Markets paid $\$ 85$ million to settle a gender discrimination case as female retail employees claimed that they were denied equal promotional opportunities as their male counterparts; Furnishings 2000 Inc., which operates 41 retail furniture and home furnishing stores in California, agreed to settle a class action gender discrimination lawsuit which was brought on them in 1988; Denny's paid \$54.4 million for their racial discrimination case; Albertson's settled their sexual and racial discrimination charges by paying $\$ 29$ to 26,000 female and Hispanic employees. Cracker Barrel paid \$2 million for settling their race discrimination case; the Boeing Corporation paid \$7.5 million for their racial discrimination case; Mitsubishi settled their sexual harassment class action lawsuit at a cost worth as high as $\$ 30$ million; Ford agreed to pay $\$ 7.5$ million to settle their racial and sexual harassment lawsuit; Lockheed Martin agreed to pay $\$ 13$ million and rehire 450 people in one of the largest age discrimination cases ever filed; Wall Street's giant Morgan Stanley agreed to settle a gender discrimination for payment of \$54 million; and Texaco agreed to pay $\$ 200,000$ each for two plaintiffs, $\$ 100,00$ each for four others, $\$ 60,000$ each for 1,340 remaining individuals in their race discrimination class action lawsuit (Chi-Hua Arlene, 1990; Lindstedt, 2004; Mujtaba, 2007; ERA, 2008). There are many other examples of large firms that have settled discrimination cases at high costs to their shareholders during the past decade. So, managers and professional workers should work on managing their perceptions, attitudes, words, non-verbal body language, behaviors, and take appropriate actions when noticing that an inappropriate comment or behavior is taking place in the work environment.

Roth (2007) stated that Shaken by sexual harassment charges and costly lawsuits, Wall Street in the late 1990s saw a real shift away from its "old boy network" past. In response to sexual harassment suits, many firms on Wall Street implemented strict sexual harassment policies, and even family friendly work-life balance policies. Unfortunately, the lawsuits have continued, prompting many to wonder why Wall Street continues to be so hostile to anyone other than white males. Roth (2007) mentions that as recently as the mid-1980s Wall Street was one big men's club, filled with smoke-filled rooms and strippers. Women, to the degree that they were all welcome at all, were relegated to roles as secretaries and sex objects. Firms blatantly discriminated against those few women who did fight to become traders, and court cases show long histories of groping, name calling, come-ons, blocked mobility, and sexual pranks (Roth, 2007). Roth's study compared 76 men and women who worked on Wall Street during the bull market of the 1990s, a market environment that should have provided a best-case scenario for the advancement of women. Based on interviews with men and women on the front lines, investment bankers, traders, etc., Roth identified four specific areas that contribute to the continued problems for anyone other than white males: a culture of around the clock devotion, parental leave, work-family policies, and sexual harassment policies.

Roth (2007) states that it is clear that diversity, sexual harassment, and work-family policies clash with Wall Street's culture and this disadvantaged women professionals. The industry is dominated by white men, many of whom have discretionary power over other workers. Blatant hostility toward women has become less common as Wall Street firms have responded to sex discrimination suits, although it still exists. Attitudes towards mothers in 
general, and the use of work-family policies also contributed to managers' assignment of the best accounts to men (Roth, 2007). Women who wanted to have families suffered disadvantages because extreme "workaholism" was a condition of work on Wall Street. Given the existence of systematic gender differences and the evidence that existing policies do not redress this inequality, Roth asks and provides answers to "what might have improved women's opportunities on Wall Street?" The answers and recommendations, according to Roth (2007) are as follows:

1. Recognizing inherent cultural biases and how they operate in this setting and most others might encourage firms to raise their awareness of these biases to a conscious level, prompting managers and workers to take a second look at women's performance when they evaluate them.

2. Companies could make managers more accountable for systematic forms of inequality, rather than introducing more "window-dressing" policies that have little impact on underlying attitudes or inequities.

3. Firms must assess the costs of losing women when they have children. If replacement and training costs are high, then there is a business case to reduce these costs by making the options more available in reality.

4. Large firms need to educate senior managers about the economic costs of attrition due to work-family conflict, and the potential economic benefits of retaining highly trained and skilled workers by accommodating their family responsibilities.

5. Making room for family life may present the biggest challenge to Wall Street's workaholic culture and its potential for gender equity, but it could help firms to retain valuable female employees and improve the opportunities of women.

Corporate managers can use new and innovative strategies to decrease the existence and occurrences of gender discrimination in their workplace. Blau and Kahn (2006) conclude that we do not expect a substantial widening of the male/female pay gap or labor force participation gap to occur. On the other hand, the gender pay gap seems unlikely to vanish in the near term. Women continue to confront discrimination in the labor market, and, although its extent seems to be decreasing, it seems unlikely to be completely eliminated soon (Blau and Kahn, 2006).

Roth (2007) mentions that despite the overall improvement in the climate within these firms, three major Wall Street firms (Citigroup's Smith Barney, Merrill Lynch, and Morgan Stanley) have each paid out more than $\$ 100$ million since the late 1990s to resolve sex discrimination suits, even while denying that any systematic discrimination against women occurs within their walls. On April 19, 2004, for instance, a panel of arbitrators awarded Hydie Sumner, a female stock broker and one of 2,800 women who brought a class action suit against Merril Lynch, \$2.2 million dollars for sex discrimination.

Roth (2007) explains that Morgan Stanley paid a settlement of \$54 million in an EEOC sex discrimination case. The lead plaintiff, Allison Schieffelin, received \$12 million and the settlement granted another \$2 million to diversity programs to promote the advancement of women within the firm. Schieffelin's case claimed that she and other female workers had been denied equitable pay and promotions, and had been excluded from company functions because of their gender. The EEOC investigated her charges and found evidence that less-deserving men had been promoted while Schieffelin, a high producer in international equity sales, remained in a lower level position, and that the firm had retaliated against her when she filed complaints. Morgan Stanely's spokesperson said that the firm disagrees with the findings and they not practice or condone discrimination of any kind.

It is obvious that there has been incremental progress with regard to the advancement of women in higher positions. However, according to Ann Pomeroy (2007), the proportion of women to men in human resource executive ranks has changed very little in the last ten years. Pomeroy explains that the traditional male "templates" and "models" of full-time, aggressive, and non-stop working careers and the gruesome path to it are not always appropriate for women. Women managers and professionals may choose to do things differently, while getting the same results. Work flexibility and opportunity are keys to attracting and retaining them. Organizational leaders need to rethink their work schedules and their definition of "dedicated" and "career-oriented" individuals if they are to make better use of each employee in their companies. Experts suggest that women need to strategically look for opportunities that will stretch their abilities and test their skills. They need to have an opportunistic mindset and aggressively pursue their dreams, objectives, and goals (Pomeroy, 2007). Without compromising your values and 
while staying within the boundaries of professionalism in the industry, Pomeroy says, do what is needed to show that you can play "the game" as well as anyone else at the senior levels. Perhaps the old model of working long hours and sacrificing family time for a corporate career does not fit today's workforce and should change to accommodate the needs of diverse generations. Ann Pomeroy says that a new model is evolving where women act as "career self-agents" and define their availability for work by their own conditions and standards. They will determine when and how the work will get done. Organizations need to create flexible work opportunities, if they are to attract and retain the best talent of both male and female genders. Karen M. Kroll (2007) writes that making the various elements of an employee's salary and compensation package more flexible so he or she can pick and choose can be very attractive to today's diverse generations of workers. It can also be very fruitful for their employers as it can lead to the recruitment, hiring and retention of experienced and productive talent. Creating equality in hiring and promotional decisions, while giving employees a little freedom in the compensation package, could lead to more satisfaction for everyone involved, higher performance for each employee, and productive departments (Kroll, 2007).

\section{STATISTICAL METHODOLOGY AND ANALYSIS}

A short, practical, and user-friendly instrument was designed specifically for the purpose of this research and to get a high response rate. The survey was delivered via email and the responses received in like manner. This method was used in order to withstand the time constraint. The response time was greatly shortened by using this method. It also gave the respondents the opportunity to respond at their own leisure and in a more private medium than via the telephone. An important factor in the decision to use this method is the cost that can be associated with survey distribution.

Six hundred surveys were sent to both male and female employees who work in various types of organizations globally. Three hundred surveys each were sent to both genders. There were 215 usable returned responses for analysis of this study. The participants had to be promoted within an organization at some point in their careers. There were no restrictions with the size, type or location of organization. The following research questions were derived from the study.

1. Is there a trend in the age group for promotion in men and women?

2. Do women have to have more work experience than men in order to be promoted?

3. Do females have to be twice as educated as males in order to be promoted?

4. Are males given promotional preferences over females?

The questionnaire was developed after the research questions were derived and the mode of distribution determined. The objective of the study was to determine if males are promoted at a faster rate than females and if so what are the factors that contribute to such decisions.

Six hundred respondents were sent emails and 215 surveys were returned yielding a response rate of $40 \%$. Of the 215 surveys, eighty five was returned with the respondent never being promoted. These were not included in the analysis.

A list of survey candidates was developed from visiting websites of various organizations and retrieving email addresses posted on their websites. Email addresses were also purchased from an email blaster. In addition, emails were sent to personal acquaintances of the researcher. In order to increase the respondent's receptiveness, the researcher must indicate how the information will be used and suggest what is expected of the respondent (Cooper $\&$ Schindler, 2001). Therefore, the survey (included in Appendix A) along with the confidentiality statement were emailed to the respondents. The respondents were given three days to respond to the survey. Upon receipt of each survey, it was entered into an excel spreadsheet database. (Appendix B). There was not any follow-up with the nonrespondents due to the time constraint. After the data was coded, it was inputted into the Statistical Package for the Social Sciences (SPSS) software which is commonly used for data of this nature. All data was analyzed using SPSS. 


\section{RESULTS AND DISCUSSIONS}

The demographic variables collected were gender, age, education, years of experience, and whether or not the individual was a minority. There were no significant differences with the population sample and the demographics. About $42.3 \%$ of the respondents were females and $57.7 \%$ were males.

Table 1 - Descriptive Statistics

\begin{tabular}{|c|c|c|c|c|c|c|c|c|c|c|c|c|c|}
\hline & \multirow{2}{*}{$\frac{\mathrm{N}}{\text { Statistic }}$} & \multirow{2}{*}{$\begin{array}{l}\text { Range } \\
\text { Statistic }\end{array}$} & \multirow{2}{*}{$\begin{array}{l}\text { Minimum } \\
\text { Statistic }\end{array}$} & \multirow{2}{*}{$\begin{array}{l}\text { Maximum } \\
\text { Statistic }\end{array}$} & \multirow{2}{*}{$\begin{array}{c}\text { Sum } \\
\text { Statistic }\end{array}$} & \multicolumn{2}{|c|}{ Mean } & \multirow{2}{*}{$\begin{array}{c}\text { Std. } \\
\text { Statistic }\end{array}$} & \multirow{2}{*}{$\begin{array}{c}\text { Variance } \\
\text { Statistic }\end{array}$} & \multicolumn{2}{|c|}{ Skewness } & \multicolumn{2}{|c|}{ Kurtosis } \\
\hline & & & & & & Statistic & Std. Error & & & Statistic & Std. Error & Statistic & Std. Error \\
\hline years & 130 & 38.97 & 36.32 & 75.29 & 6526.18 & 50.20 & 1.00 & 11.35 & 128.77 & .89 & .21 & -.54 & .42 \\
\hline educ & 130 & 11.00 & 8.00 & 19.00 & 1794.00 & 13.80 & .26 & 2.93 & 8.58 & -.22 & .21 & -.33 & .42 \\
\hline curexp & 130 & 408.00 & 96.00 & 504.00 & 39624.00 & 304.80 & 10.51 & 119.82 & 14356.69 & -.17 & .21 & -1.07 & .42 \\
\hline prevexp & 130 & 432.00 & .00 & 432.00 & 12111.00 & 93.16 & 8.35 & 95.23 & 9068.29 & 1.64 & .21 & 2.52 & .42 \\
\hline totexp & 130 & 672.00 & 132.00 & 804.00 & 51735.00 & 397.96 & 12.97 & 147.93 & 21883.88 & .26 & .21 & -.55 & .42 \\
\hline minority & 130 & 1.00 & .00 & 1.00 & 26.00 & .20 & .04 & .40 & .16 & 1.52 & .21 & .31 & .42 \\
\hline Valid N (listwise) & 130 & & & & & & & & & & & & \\
\hline
\end{tabular}

In reference to Table 2 , only $6.9 \%$ of the population was minority female and $13.1 \%$ was minority male. The average age of females at the time of promotion was 51.8 and 49 for males. In terms of education, $61.8 \%$ of females completed high school versus $20 \%$ of males - which means that a larger percentage of males went to college and graduate school. It is shown that $11 \%$ of females moved on to pursue Bachelors degrees compared to $39 \%$ of males. From the sample taken, no females had terminal degrees, while $13 \%$ of the men surveyed had doctoral level education. Overall, men had approximately one more year of experience than females.

Table 2 - Gender Statistics

\begin{tabular}{|ll|r|r|r|r|}
\hline \multirow{2}{*}{} & \multirow{2}{*}{} & \multicolumn{4}{|c|}{ gender } \\
\cline { 3 - 6 } & & \multicolumn{2}{|c|}{ female } & \multicolumn{2}{|c|}{ male } \\
\cline { 3 - 6 } years & Count & Mean & \multicolumn{2}{|c|}{ Count } & Mean \\
\hline minority & no & 46 & & 58 & \\
& yes & 9 & & 17 & \\
& 8 & & 51.8 & & 4 \\
& 12 & 9 & & 4 & \\
& 14 & 34 & & 13 & \\
& 15 & 0 & & 1 & \\
& 16 & 6 & & 29 & \\
& 17 & 6 & & 10 & \\
& 18 & 0 & & 3 & \\
totexp & 19 & 0 & & 5 & \\
\hline
\end{tabular}

Table 3 shows a strong negative correlation between education and age. There was a strong positive correlation between total experience and age. Of significance also was the negative correlation between age and education. Based on the data analysis, we can now respond to the research questions that were derived as follows.

Is there a trend in the age group for promotion in men and women? The statistics show that there is strong correlation between promotion and age. Men are promoted faster than women and it could be attributed to discrimination or the fact that men are younger than women in the workplace which could be the result of age discrimination. 
Do women have to have more work experience than men in order to be promoted? There was a strong correlation between work experience and promotion. However since males were relatively younger than females then they would have the promotional edge, demonstrating further support for age discrimination.

Table 3 - Correlation Statistics Correlations

\begin{tabular}{|c|c|c|c|c|c|c|c|}
\hline & & years & educ & curexp & prevexp & totexp & minority \\
\hline \multirow[t]{3}{*}{ years } & Pearson Correlation & 1 & $-.288^{* x}$ & -.137 & $.761^{* *}$ & $.379^{\text {*x. }}$ & $.236^{* \star}$ \\
\hline & Sig. (2-tailed) & & .001 & .119 & .000 & .000 & .007 \\
\hline & $\mathrm{N}$ & 130 & 130 & 130 & 130 & 130 & 130 \\
\hline \multirow[t]{3}{*}{ educ } & Pearson Correlation & $-.288^{* *}$ & 1 & .021 & -.152 & -.081 & -.150 \\
\hline & Sig. (2-tailed) & .001 & & .812 & .084 & .360 & .088 \\
\hline & $\mathrm{N}$ & 130 & 130 & 130 & 130 & 130 & 130 \\
\hline \multirow[t]{3}{*}{ curexp } & Pearson Correlation & -.137 & .021 & 1 & -.068 & $.766^{* *}$ & -.036 \\
\hline & Sig. (2-tailed) & .119 & .812 & & .445 & .000 & .688 \\
\hline & $\mathrm{N}$ & 130 & 130 & 130 & 130 & 130 & 130 \\
\hline \multirow[t]{3}{*}{ prevexp } & Pearson Correlation & $.761^{\star * *}$ & -.152 & -.068 & 1 & $.589^{* * \times}$ & $.255^{\star *}$ \\
\hline & Sig. (2-tailed) & .000 & .084 & .445 & & .000 & .003 \\
\hline & $\mathrm{N}$ & 130 & 130 & 130 & 130 & 130 & 130 \\
\hline \multirow[t]{3}{*}{ totexp } & Pearson Correlation & $.379^{* *}$ & -.081 & $.766^{* *}$ & $.589^{* * x}$ & 1 & .135 \\
\hline & Sig. (2-tailed) & .000 & .360 & .000 & .000 & & .124 \\
\hline & $\mathrm{N}$ & 130 & 130 & 130 & 130 & 130 & 130 \\
\hline \multirow[t]{3}{*}{ minority } & Pearson Correlation & $236^{* *}$ & -.150 & -.036 & $.255^{* *}$ & .135 & 1 \\
\hline & Sig. (2-tailed) & .007 & .088 & .688 & .003 & .124 & \\
\hline & $\mathrm{N}$ & 130 & 130 & 130 & 130 & 130 & 130 \\
\hline
\end{tabular}

**. Correlation is significant at the 0.01 level (2-tailed).

Do females have to be twice as educated as males in order to be promoted? The statistics show that the majority of women in the workplace are educated up to high school, whereas males have sought higher learning. Perhaps the attainment of higher degrees could be the main reason for the promotion of males to higher positions.

Are males given promotional preferences over females? According to the statistics, gender is not necessarily a causing factor for promotion. Age, education and experience are more likely the causing factors.

\section{CONCLUSIONS}

The results of this study show that men are more educated than women in the workplace and seemingly as a result they get promoted faster than females. The statistics also show a strong correlation between the ages of men and promotion. Males may be promoted as a result of higher educational levels or perhaps due to being relatively younger than females, which is often translated to the opinion that they can offer longer years of service. Compared to women, men are promoted at a younger age. The data also shows that total experience and years of service also resulted in higher "promote-ability." As more and more women enter the workforce, the challenge to move up the ladder becomes greater. The statistics show that there are more educated men in the workplace despite the fact that previous research has shown that more females are at higher educational level than males. Is it an indication that more women are running their own businesses, working from home, or just staying at home to take care of their children or families? The statistics show that men have a better chance of getting promoted because they are both younger and more educated. It also seems that minorities have the opportunity of being promoted because of their tenure in the organization.

Women's credibility and ability are often questioned and compared with that of male counterparts. It is still believed that women with the same educational background and work experience as men do not receive the same benefits, are at lower levels and receive fewer promotions. One can therefore conclude that men are not necessarily given preferential treatment over women because of gender, but because of other factors like education, age and work experience. 
There is much work to be done on this type of research. While there might not always be gender discrimination, it is believed that societal biases and discriminatory practices still exist in the workplace. Such biases and practices tend to favor males and come at a cost to female candidates. Future researchers should increase the sample size and conduct a more scientifically accurate study to determine why it is perceived that men are often promoted at a higher rate them females. Future researchers can also study actual promotions rather than self-reported promotions which is another limitation of this study. This study did not support this assertion that males are given promotional preferences over their female counterparts. The implications of this study are that, while biases and discriminatory practices still do exist in the workplace, female employees should not automatically believe that their gender will keep them from getting promoted. Rather, female candidates are encouraged to continue their goals of aiming for higher positions in the company by discussing each objective with their superiors, jointly setting achievable targets, and getting the relevant skills and experience needed to effectively prepare themselves for the upcoming promotion. Similarly, managers are encouraged to thoroughly review all possible candidates for promotional opportunities and make fair decisions for those who deserve to move up the hierarchy based on practical and academic qualifications. Mujtaba and Sims (2006) state the formal training programs can help managers make better decision and more ethical decisions. Therefore, employers can offer specific training programs for their managers to effectively, ethical, and fairly make promotion decisions.

\section{AUTHOR INFORMATION}

Charmaine C. Walters Balfour is a doctoral student majoring in finance at the Nova Southeastern University. Charmaine has over ten years in corporate accounting. Her research interest is in international finance

Bahaudin G. Mujtaba, D.B.A., is an Associate Professor of Management and Human Resources Management at Nova Southeastern University's H. Wayne Huizenga School of Business and Entrepreneurship. Bahaudin has served as manager, trainer and management development specialist in the corporate world as well as a director, department chair and faculty member in academia. His areas of research are management, training, diversity management, and cross-cultural management.

\section{REFERENCES}

1. Adair, C. K. (1994). Cracking the glass ceiling: Factors influencing women's attainment of senior executive positions. Retrieved December 12, 2006 from http://dissertation.com

2. Blau, F. D. and Kahn, L. M. (2007). The Gender Pay Gap: Have Women Gone as Far as They Can? The Academy of Management Perspectives, 21 (1), 1-24.

3. Bullard, A.M. \& Wright, D.S. (1993). Circumventing the glass ceiling: Women executives in American state governments. Public Administration Review, 53(3), 189-202

4. Chi-Hue Arlene, J. (1990). Furnishings 2000 Inc. agrees to settle class action lawsuit. Business Wire, New York: February 22, 1990. Sec. 1.

5. $\quad$ Cooper, D., \& Schindler, P. (2001). Business research methods. New York: McGraw-Hill.

6. $\quad$ ERA (2008). Retail discrimination project: Duke v. Wal-Mart Stores. Equal Rights Project. Retrieved on 11, 30, 2008 from: www.equalrights.org/professional/retail.asp

7. Foley, S. (1998). The effects of the actual and perceived glass ceiling on perceptions of promotion fairness. Retrieved December, 6, 2006 from http://umi.com

8. Hofstede, G. (1980). Culture's consequences: International differences in work-related values. Beverly Hills, C.A.: Sage

9. Johnson, W. U. (2005). Differences in perceptions of factors influencing the advancement of African American women in the workplace. Dissertation at Walden University.

10. Kroll, K. M. (April 2007). Let's Get Flexible: Despite challenges, companies are getting more flexible with their total compensation packages. HRMagazine, 54(4), pp. 97-100.

11. Landau, J. (1995). The relationship of race and gender to managers' ratings of promotion Potential. Journal of Organizational Behavior, 16(4), 391.

12. Linstedt, S. (2004). The Buffalo News, N.Y., Sharon Linstedt column. Knight Ridder Tribune Business News, Washington: June 22, 2004 
13. Lyness, K.S. \& Schrader, C.A. (2006). Moving ahead or just moving? An examination of gender differences in senior corporate management appointments. Group and Organization ManagementThousand Oaks, 31(6), 651

14. Lyness, K. S., \& Thompson, D. E. (2000). Do female and male executives follow the same route? Journal of Applied Psychology, 85(1), 86-101

15. Mihail, D. M., (2006). Women in management: Gender stereotypes and students' attitudes in Greece. Women in Management Review-Bradford, 21(8), 681.

16. Mujtaba, B. G. (2007). Workplace Diversity Management: Challenges, Competencies and Strategies. Llumina Press, Davie, Florida.

17. Mujtaba, B. and Sims, R. L. (2006). Socializing Retail Employees in Ethical Values: The Effectiveness of the Formal versus Informal Methods. Journal of Business and Psychology, 21(2), 261-272.

18. Pomeroy, Ann (April 2007). Peak Performances: Tough choices, mentors and broad experience are critical for women who hope to climb the HR executive ranks. HRMagazine, 54(4), pp. 49-53.

19. Risher, H. (2005). How much should federal employees be paid? The problems with using a market philosophy in a broad band system. Public Personnel Management, 34 (2), pp. 121-140.

20. Roth, L.M. (2007). Women on Wall Street: Despite Diversity Measures, Wall Street Remains Vulnerable to Sex Discrimination Charges. The Academy of Management Perspectives, 21 (1), 24-35.

21. Parkinson, G., (2006). Women still struggle to break through FTSE's glass ceiling. The Independent U.K., p. 49.

22. Winchester, H., Lorenzo, S., Browning, L., \& Chesterman, C. (2006). Academic women's promotions in Australian universities. Employee Relations-Bradford, 28(6), 505.

23. Women still fear bias. Retrieved from Proquest on December 1, 2006 at http://0proquest.umi.com.novacat.nova.edu/pqdweb?did=1159669941\&sid=1\&Fmt $=3 \&$ clientId=17038\&RQT $=30$ 9\&VName=PQD

24. Wal-Mart Worker, (2008). Wal-Mart worker killed as crowd storms store. The Gainesville Sun, 4A, September 29, 2008.

25. Weber, L. (2004). Judge grants suit against Wal-Mart Class-Action status. Knight Ridder Tribune Business News, Washington: June 23, 2004

\section{APPENDIX A - THE SURVEY INSTRUMENT}

\section{Part A - Directions:}

The purpose of this study is to determine whether males are promoted at a faster rate than females who are equally qualified.

Your identity will be completely anonymous. This questionnaire takes only two minutes to complete. Your participation involves responding to the questions below and emailing your response within three days.

If you have any questions regarding this research study please call Charmaine B. at 678-567-1198 or email waltersb@nova.edu. Thank you for your assistance.

Sincerely,

Charmaine B.

Part B - Survey Questions:

1. What gender are you? ( ) Male ( ) Female

2. Have you ever been promoted within an organization? ( ) Yes ( ) No

3. What was your age at the time of your promotion?

4. How many months of experience do you have at your current job?

5. How much previous work experience do you have?

6. How many years of school have you completed?

7. Are you an ethnic minority? ( ) Yes ( ) No

THANK YOU! 
APPENDIX B - DATA COMPILATION

\begin{tabular}{|c|c|c|c|c|c|c|c|}
\hline id & gender & Years & Educ & curexp & prevexp & totexp & Minority \\
\hline 4 & $\mathrm{f}$ & 57.79 & 15 & 96 & 137 & 233 & 1 \\
\hline 8 & $\mathrm{f}$ & 66.89 & 12 & 108 & 48 & 156 & 0 \\
\hline 9 & $\mathrm{f}$ & 73.71 & 12 & 108 & 124 & 232 & 1 \\
\hline 14 & $\mathrm{f}$ & 43.35 & 8 & 120 & 52 & 172 & 0 \\
\hline 22 & $\mathrm{f}$ & 39.28 & 15 & 156 & 11 & 167 & 0 \\
\hline 23 & $\mathrm{f}$ & 45.55 & 16 & 156 & 22 & 178 & 0 \\
\hline 24 & $\mathrm{f}$ & 39.11 & 12 & 168 & 24 & 192 & 0 \\
\hline 30 & $\mathrm{f}$ & 74.91 & 12 & 192 & 205 & 397 & 0 \\
\hline 31 & $\mathrm{f}$ & 42.78 & 12 & 192 & 48 & 240 & 0 \\
\hline 33 & $\mathrm{f}$ & 40.08 & 12 & 216 & 34 & 250 & 0 \\
\hline 34 & $\mathrm{f}$ & 75.29 & 8 & 216 & 412 & 628 & 0 \\
\hline 37 & $\mathrm{f}$ & 42.23 & 12 & 228 & 11 & 239 & 1 \\
\hline 40 & $\mathrm{f}$ & 64.42 & 12 & 240 & 156 & 396 & 0 \\
\hline 41 & $\mathrm{f}$ & 44.64 & 16 & 240 & 19 & 259 & 0 \\
\hline 44 & $\mathrm{f}$ & 72.85 & 12 & 264 & 208 & 472 & 0 \\
\hline 45 & $\mathrm{f}$ & 74.07 & 8 & 264 & 35 & 299 & 0 \\
\hline 46 & $\mathrm{f}$ & 68.68 & 15 & 264 & 231 & 495 & 1 \\
\hline 53 & $\mathrm{f}$ & 59.56 & 12 & 288 & 97 & 385 & 0 \\
\hline 54 & $\mathrm{f}$ & 64.75 & 8 & 288 & 48 & 336 & 0 \\
\hline 55 & $\mathrm{f}$ & 72.06 & 12 & 288 & 0 & 288 & 0 \\
\hline 56 & $\mathrm{f}$ & 42.48 & 16 & 288 & 4 & 292 & 0 \\
\hline 57 & $\mathrm{f}$ & 43.23 & 15 & 288 & 51 & 339 & 0 \\
\hline 58 & $\mathrm{f}$ & 66.31 & 12 & 288 & 358 & 646 & 0 \\
\hline 60 & $\mathrm{f}$ & 37.52 & 12 & 300 & 0 & 300 & 0 \\
\hline 61 & $\mathrm{f}$ & 37.60 & 12 & 300 & 11 & 311 & 0 \\
\hline 62 & $\mathrm{f}$ & 37.90 & 12 & 300 & 13 & 313 & 0 \\
\hline 63 & $\mathrm{f}$ & 64.81 & 8 & 300 & 0 & 300 & 1 \\
\hline 67 & $\mathrm{f}$ & 38.48 & 12 & 312 & 8 & 320 & 0 \\
\hline 68 & $\mathrm{f}$ & 43.18 & 16 & 312 & 3 & 315 & 0 \\
\hline 73 & $\mathrm{f}$ & 37.15 & 12 & 324 & 5 & 329 & 0 \\
\hline 77 & $\mathrm{f}$ & 40.30 & 12 & 336 & 47 & 383 & 0 \\
\hline 80 & $\mathrm{f}$ & 55.82 & 12 & 348 & 63 & 411 & 0 \\
\hline 81 & $\mathrm{f}$ & 43.76 & 12 & 348 & 64 & 412 & 0 \\
\hline 82 & $\mathrm{f}$ & 37.13 & 12 & 348 & 0 & 348 & 0 \\
\hline 83 & $\mathrm{f}$ & 40.05 & 12 & 348 & 38 & 386 & 0 \\
\hline 86 & $\mathrm{f}$ & 39.59 & 15 & 360 & 7 & 367 & 0 \\
\hline 87 & $\mathrm{f}$ & 40.16 & 12 & 360 & 22 & 382 & 0 \\
\hline 91 & $\mathrm{f}$ & 64.85 & 12 & 372 & 144 & 516 & 0 \\
\hline 94 & $\mathrm{f}$ & 73.05 & 8 & 396 & 159 & 555 & 0 \\
\hline 97 & $\mathrm{f}$ & 40.51 & 12 & 408 & 18 & 426 & 0 \\
\hline 99 & $\mathrm{f}$ & 58.16 & 8 & 408 & 194 & 602 & 1 \\
\hline 100 & $\mathrm{f}$ & 64.56 & 12 & 408 & 271 & 679 & 1 \\
\hline 102 & $\mathrm{f}$ & 43.90 & 16 & 420 & 12 & 432 & 0 \\
\hline 104 & $\mathrm{f}$ & 68.59 & 8 & 432 & 102 & 534 & 0 \\
\hline 107 & $\mathrm{f}$ & 36.85 & 8 & 444 & 17 & 461 & 0 \\
\hline 108 & $\mathrm{f}$ & 36.76 & 12 & 444 & 2 & 446 & 0 \\
\hline 109 & $\mathrm{f}$ & 36.32 & 12 & 444 & 0 & 444 & 0 \\
\hline 110 & $\mathrm{f}$ & 37.35 & 12 & 444 & 20 & 464 & 0 \\
\hline 111 & $\mathrm{f}$ & 36.85 & 12 & 444 & 2 & 446 & 0 \\
\hline 112 & $\mathrm{f}$ & 53.62 & 12 & 444 & 121 & 565 & 1 \\
\hline 115 & $\mathrm{f}$ & 40.75 & 16 & 456 & 11 & 467 & 0 \\
\hline 120 & $\mathrm{f}$ & 70.63 & 12 & 468 & 196 & 664 & 0 \\
\hline 121 & $\mathrm{f}$ & 64.88 & 12 & 468 & 181 & 649 & 0 \\
\hline 126 & $\mathrm{f}$ & 73.52 & 12 & 480 & 163 & 643 & 1 \\
\hline 130 & $\mathrm{f}$ & 42.53 & 15 & 504 & 57 & 561 & 0 \\
\hline
\end{tabular}


Journal of Diversity Management - Second Quarter 2009

Volume 4, Number 2

\begin{tabular}{|c|c|c|c|c|c|c|c|}
\hline id & gender & Years & Educ & curexp & prevexp & totexp & Minority \\
\hline 1 & $\mathrm{~m}$ & 54.86 & 15 & 96 & 144 & 240 & 0 \\
\hline 2 & $\mathrm{~m}$ & 48.56 & 16 & 96 & 36 & 132 & 0 \\
\hline 3 & $\mathrm{~m}$ & 48.31 & 15 & 96 & 67 & 163 & 0 \\
\hline 5 & $\mathrm{~m}$ & 44.40 & 15 & 108 & 48 & 156 & 0 \\
\hline 6 & $\mathrm{~m}$ & 50.73 & 16 & 108 & 70 & 178 & 0 \\
\hline 7 & $\mathrm{~m}$ & 44.32 & 12 & 108 & 103 & 211 & 0 \\
\hline 10 & $\mathrm{~m}$ & 40.10 & 15 & 120 & 14 & 134 & 0 \\
\hline 11 & $\mathrm{~m}$ & 62.87 & 19 & 120 & 199 & 319 & 0 \\
\hline 12 & $\mathrm{~m}$ & 45.74 & 15 & 120 & 68 & 188 & 0 \\
\hline 13 & $\mathrm{~m}$ & 57.86 & 19 & 120 & 175 & 295 & 0 \\
\hline 15 & $\mathrm{~m}$ & 52.18 & 12 & 120 & 113 & 233 & 1 \\
\hline 16 & $\mathrm{~m}$ & 46.47 & 16 & 120 & 46 & 166 & 1 \\
\hline 17 & $\mathrm{~m}$ & 46.22 & 15 & 132 & 90 & 222 & 0 \\
\hline 18 & $\mathrm{~m}$ & 68.36 & 12 & 132 & 307 & 439 & 0 \\
\hline 19 & $\mathrm{~m}$ & 48.24 & 15 & 144 & 93 & 237 & 0 \\
\hline 20 & $\mathrm{~m}$ & 42.71 & 8 & 156 & 41 & 197 & 0 \\
\hline 21 & $\mathrm{~m}$ & 46.47 & 16 & 156 & 34 & 190 & 0 \\
\hline 25 & $\mathrm{~m}$ & 73.20 & 8 & 168 & 432 & 600 & 1 \\
\hline 26 & $\mathrm{~m}$ & 43.13 & 18 & 180 & 47 & 227 & 0 \\
\hline 27 & $\mathrm{~m}$ & 47.74 & 19 & 180 & 68 & 248 & 0 \\
\hline 28 & $\mathrm{~m}$ & 54.12 & 15 & 180 & 151 & 331 & 1 \\
\hline 29 & $\mathrm{~m}$ & 45.59 & 15 & 192 & 85 & 277 & 0 \\
\hline 32 & $\mathrm{~m}$ & 55.89 & 15 & 192 & 191 & 383 & 1 \\
\hline 35 & $\mathrm{~m}$ & 42.91 & 12 & 216 & 38 & 254 & 1 \\
\hline 36 & $\mathrm{~m}$ & 43.92 & 15 & 228 & 56 & 284 & 1 \\
\hline 38 & $\mathrm{~m}$ & 55.30 & 16 & 240 & 150 & 390 & 0 \\
\hline 39 & $\mathrm{~m}$ & 41.09 & 15 & 240 & 25 & 265 & 0 \\
\hline 42 & $\mathrm{~m}$ & 42.50 & 12 & 240 & 38 & 278 & 1 \\
\hline 43 & $\mathrm{~m}$ & 68.93 & 8 & 252 & 171 & 423 & 0 \\
\hline 47 & $\mathrm{~m}$ & 44.20 & 15 & 276 & 49 & 325 & 0 \\
\hline 48 & $\mathrm{~m}$ & 46.14 & 15 & 276 & 69 & 345 & 0 \\
\hline 49 & $\mathrm{~m}$ & 42.58 & 15 & 288 & 72 & 360 & 0 \\
\hline 50 & $\mathrm{~m}$ & 57.75 & 16 & 288 & 149 & 437 & 0 \\
\hline 51 & $\mathrm{~m}$ & 43.86 & 12 & 288 & 32 & 320 & 0 \\
\hline 52 & $\mathrm{~m}$ & 43.32 & 12 & 288 & 85 & 373 & 0 \\
\hline 59 & $\mathrm{~m}$ & 72.85 & 15 & 288 & 371 & 659 & 1 \\
\hline 64 & $\mathrm{~m}$ & 42.84 & 18 & 312 & 29 & 341 & 0 \\
\hline 65 & $\mathrm{~m}$ & 58.94 & 19 & 312 & 221 & 533 & 0 \\
\hline 66 & $\mathrm{~m}$ & 55.22 & 19 & 312 & 199 & 511 & 0 \\
\hline 69 & $\mathrm{~m}$ & 40.74 & 15 & 324 & 38 & 362 & 0 \\
\hline 70 & $\mathrm{~m}$ & 59.12 & 15 & 324 & 261 & 585 & 0 \\
\hline 71 & $\mathrm{~m}$ & 42.49 & 18 & 324 & 30 & 354 & 0 \\
\hline 72 & $\mathrm{~m}$ & 42.36 & 16 & 324 & 12 & 336 & 0 \\
\hline 74 & $\mathrm{~m}$ & 41.90 & 16 & 336 & 20 & 356 & 0 \\
\hline 75 & $\mathrm{~m}$ & 42.13 & 17 & 336 & 26 & 362 & 0 \\
\hline 76 & $\mathrm{~m}$ & 41.23 & 15 & 336 & 24 & 360 & 0 \\
\hline 78 & $\mathrm{~m}$ & 68.84 & 12 & 336 & 281 & 617 & 1 \\
\hline 79 & $\mathrm{~m}$ & 43.86 & 15 & 348 & 63 & 411 & 0 \\
\hline 84 & $\mathrm{~m}$ & 46.91 & 15 & 348 & 52 & 400 & 1 \\
\hline 85 & $\mathrm{~m}$ & 70.09 & 12 & 360 & 385 & 745 & 0 \\
\hline 88 & $\mathrm{~m}$ & 48.39 & 8 & 360 & 144 & 504 & 1 \\
\hline 89 & $\mathrm{~m}$ & 54.13 & 18 & 372 & 125 & 497 & 0 \\
\hline 90 & $\mathrm{~m}$ & 48.30 & 18 & 372 & 74 & 446 & 0 \\
\hline 92 & $\mathrm{~m}$ & 42.92 & 16 & 384 & 45 & 429 & 0 \\
\hline 93 & $\mathrm{~m}$ & 43.17 & 12 & 396 & 72 & 468 & 0 \\
\hline 95 & $\mathrm{~m}$ & 51.76 & 12 & 396 & 155 & 551 & 1 \\
\hline 96 & $\mathrm{~m}$ & 45.57 & 15 & 408 & 83 & 491 & 0 \\
\hline 98 & $\mathrm{~m}$ & 52.53 & 16 & 408 & 138 & 546 & 1 \\
\hline 101 & $\mathrm{~m}$ & 39.08 & 14 & 420 & 15 & 435 & 0 \\
\hline
\end{tabular}




\begin{tabular}{cccccccc} 
id & gender & Years & Educ & curexp & prevexp & totexp & Minority \\
\hline 103 & $\mathrm{~m}$ & 71.31 & 15 & 432 & 372 & 804 & 0 \\
105 & $\mathrm{~m}$ & 45.53 & 17 & 432 & 67 & 499 & 1 \\
106 & $\mathrm{~m}$ & 41.86 & 19 & 444 & 74 & 518 & 0 \\
113 & $\mathrm{~m}$ & 41.19 & 17 & 456 & 17 & 473 & 0 \\
114 & $\mathrm{~m}$ & 44.06 & 19 & 456 & 21 & 477 & 0 \\
116 & $\mathrm{~m}$ & 43.62 & 15 & 456 & 70 & 526 & 1 \\
117 & $\mathrm{~m}$ & 41.52 & 15 & 468 & 46 & 514 & 0 \\
118 & $\mathrm{~m}$ & 49.41 & 19 & 468 & 75 & 543 & 0 \\
119 & $\mathrm{~m}$ & 45.11 & 15 & 468 & 96 & 564 & 0 \\
122 & $\mathrm{~m}$ & 40.08 & 12 & 480 & 47 & 527 & 0 \\
123 & $\mathrm{~m}$ & 42.55 & 15 & 480 & 80 & 560 & 0 \\
124 & $\mathrm{~m}$ & 42.17 & 15 & 480 & 64 & 544 & 0 \\
125 & $\mathrm{~m}$ & 45.45 & 15 & 480 & 86 & 566 & 1 \\
127 & $\mathrm{~m}$ & 53.33 & 12 & 492 & 210 & 702 & 0 \\
128 & $\mathrm{~m}$ & 47.16 & 19 & 492 & 54 & 546 & 0 \\
129 & $\mathrm{~m}$ & 44.73 & 19 & 504 & 27 & 531 & 0 \\
\hline
\end{tabular}

\section{NOTES}

